\title{
Fertility in Alberta in a Context of Rapid Economic Growth, 1997-2007
}

\author{
Frank Trovato \\ Population Research Laboratory \\ and Department of Sociology \\ University of Alberta \\ Edmonton, Alberta \\ Canada, T6G 2H4 \\ E-mail: ftrovato@ualberta.ca
}

\begin{abstract}
Historically, birth rates in Alberta have followed closely the trajectory of change experienced by the other Canadian provinces. Its total fertility rate fell during the low point of the 1930s; it increased during the postWar baby boom in the 1950s and sixties, and thereafter fell to subreplacement levels beginning in the mid 1970s. In recent years, especially since the early 2000s, the birth rate in Alberta has unexpectedly increased, such that by 2007, it had reached 1.90 children per woman-not far from the 2.1 level needed for generational replacement in the long term. During this same period both national and provincial fertility rates fluctuated at levels below those of Alberta (except Saskatchewan and Manitoba, whose rates have been higher). In this study, I examine the historical pattern of fertility change in Alberta, noting similarities and differences with the other provinces. I then look at the association of selected macro level factors (marriage, unemployment, wages, female labour force participation) with change in total and parity-specific birth rates between 1997 and 2007, a period of unprecedented economic growth in Alberta. The statistical results show that although marriage is not significantly correlated with change in fertility rates, male and female wages and female labour force participation all show associations consistent with a procyclical interpretation of fertility change - that is, periods of economic growth are conducive to fertility increase whereas bad economic times are associated with reduced fertility.
\end{abstract}

Key Words: Total fertility; birth order specific fertility; economy

CSP 2010, 37.3-4: 497-524 


\begin{abstract}
Résumé
Historiquement, les taux des naissances en Alberta on suivi de près la trajectoire de changements des autres provinces canadiennes. Son indice synthétique de fécondité a chuté pendant le point bas des années 1930, est remonté pendant le baby-boom de l'après-guerre des années 1950 et 1960 pour ensuite retomber sous le seuil de remplacement dès le milieu des années 1970. Au cours des dernières années, et particulièrement depuis le début des années 2000, le taux des naissances en Alberta a augmenté de façon inattendue, à tel point qu'en 2007, il avait atteint 1.90 enfant par femme - pas loin du niveau de 2.1 requis pour le remplacement générationnel à long terme. Pendant cette même période de temps, le taux des naissances à l'échelle nationale et provinciale a fluctué à des niveaux en dessous de ceux de l'Alberta (sauf en Saskatchewan et au Manitoba où le taux des naissances est plus élevé). Dans cette étude, j'examine les changements dans les tendances historiques de fécondité en Alberta, en notant les similarités et les différences avec les autres provinces. Puis, j'observe la connexion entre certains facteurs de macro-niveau (mariage, chômage, salaires, taux d'activité féminine) et les changements dans le taux des naissances totales et par parité entre 1997 et 2007, une période de croissance économique sans précédent pour l'Alberta. Les résultats statistiques montrent que bien que le mariage n'est pas corrélé de manière importante avec les changements du taux de fécondité, les salaires des hommes et des femmes et le taux d'activité féminine montrent tous une corrélation consistante avec une interprétation procyclique des changements dans le taux de fécondité.
\end{abstract}

Mots-clés: Natalité totale, fécondité spécifique au rang de naissance, économie

\title{
Introduction
}

Similar to most other highly developed countries, fertility in Canada has been well below the replacement level of 2.1 children per woman for almost four decades. This situation can be partly attributed to long term declines in marriage among young adults, many of whom have sought to postpone matrimony and parenthood to older ages or forgo these altogether (Balakrishnan, Lapierre-Adamcyk and Krotki 1993; LapierreAdamcyk and Charvet 2000; Le Bourdais and Lapierre-Adamcyk 2004; $\mathrm{Wu}$ 2000). Such demographic developments can only be understood in 
their full complexity through careful systematic analysis of their social, cultural, and economic foundations. This study is concerned with one aspect of the overall picture regarding fertility in Canada. The focus is on the case of Alberta, where over recent years, particularly since the early 2000 s, this province has witnessed an unexpected surge in total fertility, such that by 2007 it had reached 1.90 children per woman, thus very close to the 2.1 replacement level. ${ }^{1}$ In tandem with these development the annual number of births have been increasing significantly from year to year, exceeding 50,000 for the first time in 2008. ${ }^{2}$ Figure 1 compares the total fertility rates (TFRs) of Alberta and Canada between 1997 and 2007. Though irregular, the Alberta rate throughout this period has followed an upward progression, showing pronounced increases after 2000, whereas for Canada TFR shows little change until 2006. This upward movement in national fertility is to a large extent attributable to the strong contribution of Alberta. ${ }^{3}$

A defining feature of Alberta's post-War economy are two protracted booms driven by sharp increases in world demand for natural gas and hydrocarbons, the province's two leading natural resources. Both booms attracted massive migratory flows to this province from other parts of Canada and to a lesser extent from abroad (Hiller 2009; Parkland Institute 2007; Marsh 2006; Owram 2006). The first economic boom started in 1973 and lasted until 1982, when the province fell into a prolonged downturn that persisted until 1996, at which point a new period of intense growth broke out (Cross and Bowlby 2006; Hiller 2009). At the height of this recent expansion unemployment fell to just 3.4 per cent in 2005 , well below the national average of 6.3 per cent. In that year, the median family income in Alberta was, next to Ontario, the second highest in the country (see Table 1). From 2002 to 2005, the Gross Domestic Product (GDP) of Alberta rose by an average rate of 12.7 per cent annually. To put this in perspective, China, the strongest economy in the world experienced annual average GDP increases of 14.8 per cent during this same interval (Cross and Bowlby 2006). In late 2008, economic expansion in Alberta dampened considerably as a result of the financial crisis in the United States. ${ }^{4}$

\section{Study Objectives}

In this study the relationship between changes in selected socio-economic indicators for Alberta and fertility between 1997 and 2007 is examined. A related question explored is the extent to which the fertility rise in Alberta is attributable to change in order-specific birth rates. These objectives are executed through a series of correlations involving parity- 
Figure 1. Total Fertility Rates

for Canada and Alberta: 1997 - 2007

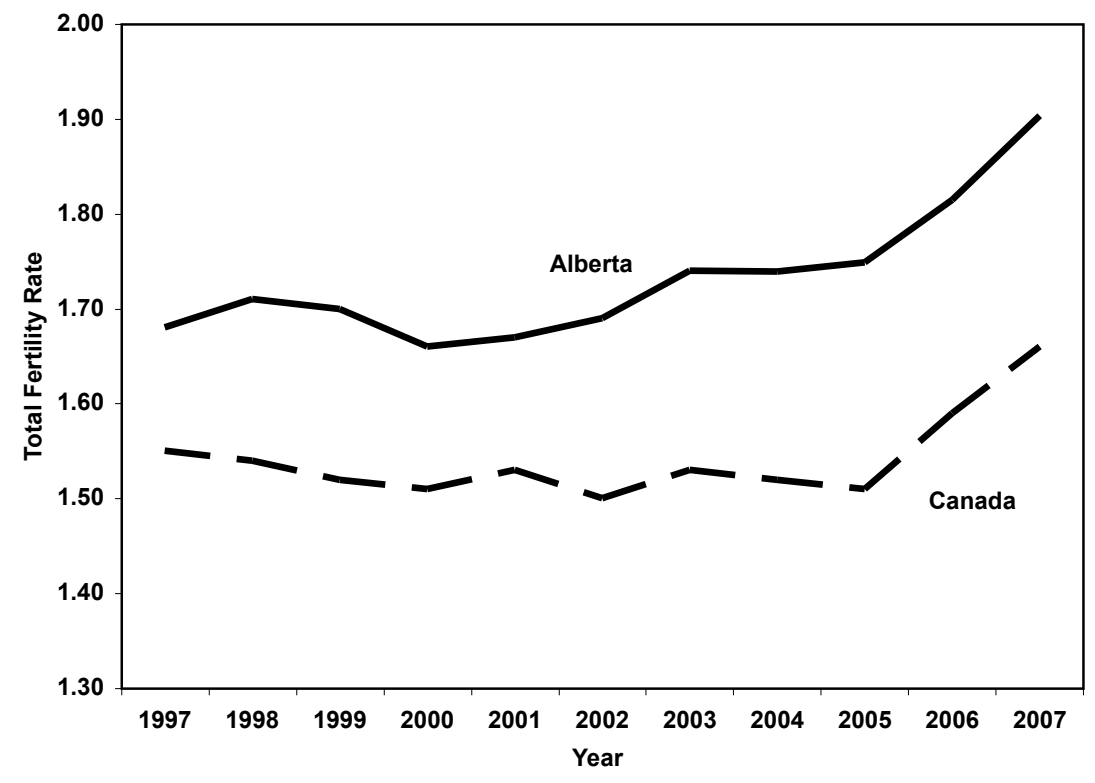

Source: Alberta Vital Statistics Annual Reports; Statistics Canada Annual Vital Statistics, Births; and CANSIM data base. 
Table 1

Labour Force Statistics and Median Earnings for Canada and Provinces: 2005

\begin{tabular}{l|c|c|c|c}
\hline \multicolumn{1}{c|}{ Province } & $\begin{array}{c}\text { Participation } \\
\text { Rate \% }\end{array}$ & $\begin{array}{c}\text { Employment } \\
\text { Rate \% }\end{array}$ & $\begin{array}{c}\text { Unemployment } \\
\text { Rate \% }\end{array}$ & $\begin{array}{c}\text { Median } \\
\text { Family } \\
\text { Income }\end{array}$ \\
\hline \hline Canada & $\mathbf{6 7 . 2}$ & $\mathbf{6 3}$ & $\mathbf{6 . 3}$ & $\mathbf{\$ 4 1 , 4 0 1}$ \\
Newfoundland \& Labrador & 59.2 & 50.4 & 14.8 & $\$ 37,429$ \\
Prince Edward Island & 68.7 & 61.1 & 11.0 & $\$ 34,140$ \\
Nova Scotia & 62.9 & 57.9 & 7.9 & $\$ 36,917$ \\
New Brunswick & 63.7 & 58.1 & 8.8 & $\$ 35,288$ \\
Quebec & 65.5 & 60.2 & 8.0 & $\$ 37,222$ \\
Ontario & 67.7 & 63.5 & 6.3 & $\$ 44,748$ \\
Manitoba & 68.8 & 65.8 & 4.3 & $\$ 36,692$ \\
Saskatchewan & 69.1 & 65.9 & 4.7 & $\$ 35,948$ \\
Alberta & 73.4 & 70.8 & 3.4 & $\$ 43,964$ \\
British Columbia & 65.7 & 62.5 & 4.8 & \\
\hline
\end{tabular}

Sources: Alberta Employment, Immigration and Industry. 2007. Annual Alberta Regional

Labour Market Review, p. 3; Statistics Canada. 2008. Earnings and Incomes of Canadians Over

the Past Quarter Century, 2006 Census. Cat. No. 97-563-X, p. 14.

Note: 2005 constant dollars; full time-wage earners, excluding the self-employed. 
specific birth rates and selected macroeconomic and demographic variables. The main proposition underlying this analysis is that sustained economic growth in Alberta during this period has fostered a socioeconomic environment conducive to fertility increase. In order to place this study in proper perspective, before proceeding to these objectives, a brief historical overview of fertility change across the provinces and territories is reviewed. Data for Northwest Territories and Yukon is available since 1951 and for Nunavut since 1989. The series for Newfoundland start in 1988; and for Quebec in 1926. For the other provinces the data extend back to $1921 .{ }^{5}$

\section{Provincial Fertility Patterns: Historical Overview}

Over the course of the 20th century provincial birth rates in Canada have fluctuated through the low period of the 1930s, the post-War baby boom between 1946 and 1966, and thereafter a continuing decline toward below replacement levels in the early years of the 1970s (Grindstaff 1995, 1985, 1975; Romaniuk 1984). The following index is applied, based on the Canadian TFR as the standard:

$$
\theta_{\mathrm{i}(\mathrm{t})}=T F R_{\mathrm{i}(\mathrm{t})}-T F R_{(\mathrm{t})}
$$

Where $\theta_{\mathrm{i}(\mathrm{t})}$ indexes TFR difference for a province/territory $i$ in year $t$ in relation to Canada in year $t ; T F R_{\mathrm{i}(\mathrm{t})}$ is the total fertility rate for a province/territory; and $T F R^{*}{ }_{(\mathrm{t})}$ is the Canadian TFR. An index value of zero would denote identical fertility between a given province/territory and the nation; a positive difference means above average fertility for a province/territory; and a negative value indicates reduced fertility for a province/territory in relation to Canada.

In Figure 3, the Atlantic provinces of Prince Edward Island, Nova Scotia and New Brunswick and Newfoundland, had by the mid 1980s, witnessed their birth rates fall below the Canadian level. Prince Edward Island's TFR converged with Canada relatively late, at the turn of the new millennium. Regarding Ontario and Quebec, from the early 1920s through to the early 1960s their TFRs have shown opposite trajectories: Early in the century the Quebec rate was well above the Canadian average while Ontario's was noticeably lower. As the century progressed, birth rates in Quebec fell dramatically and eventually converged with Canada by 1961. Ontario's upward movement reached convergence with Canada in the later part of the 1960s. Notwithstanding these different trajectories, since the early 1990s the birth rates of these two provinces 


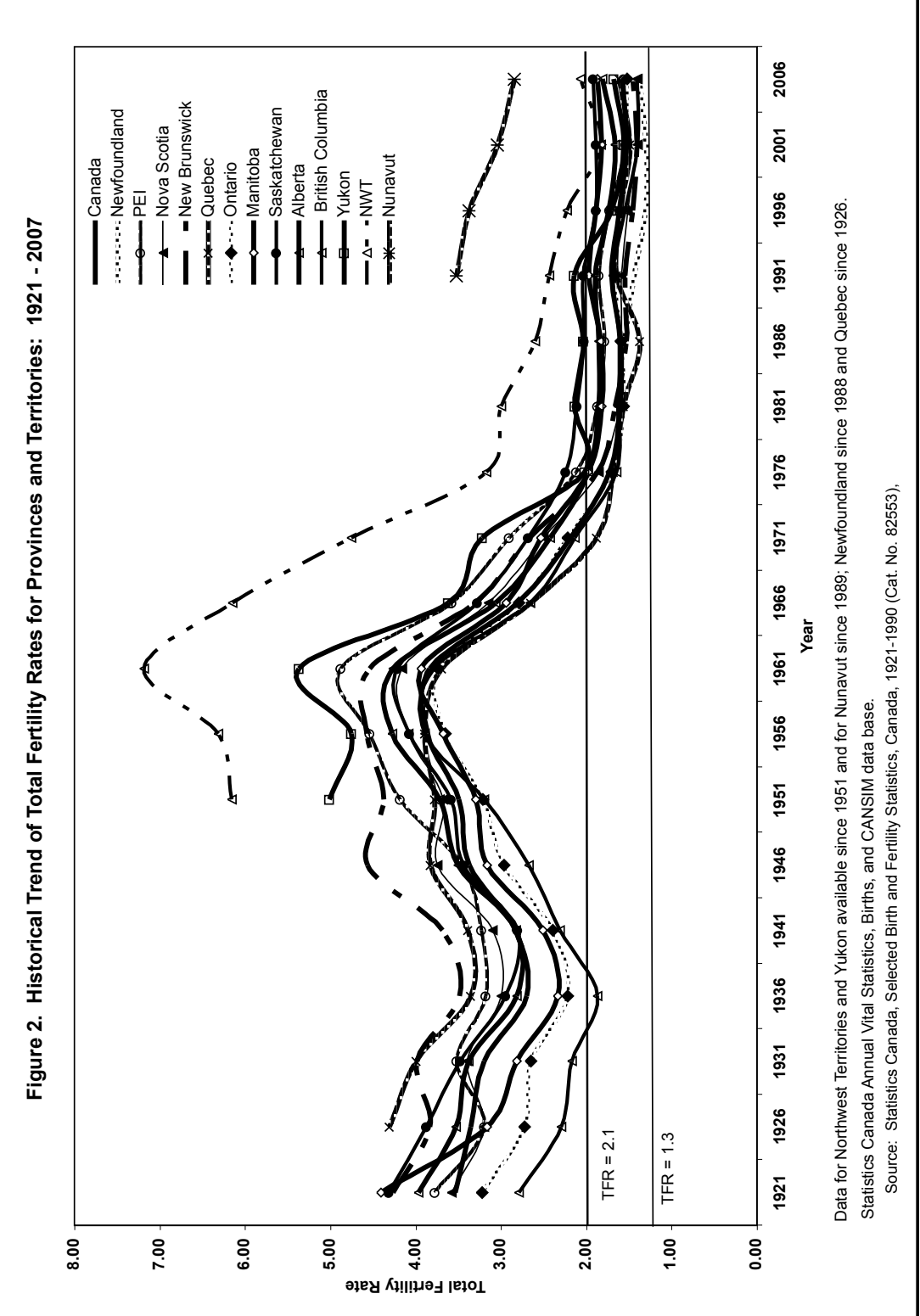

CSP 2010, 37.3-4: 497-524 


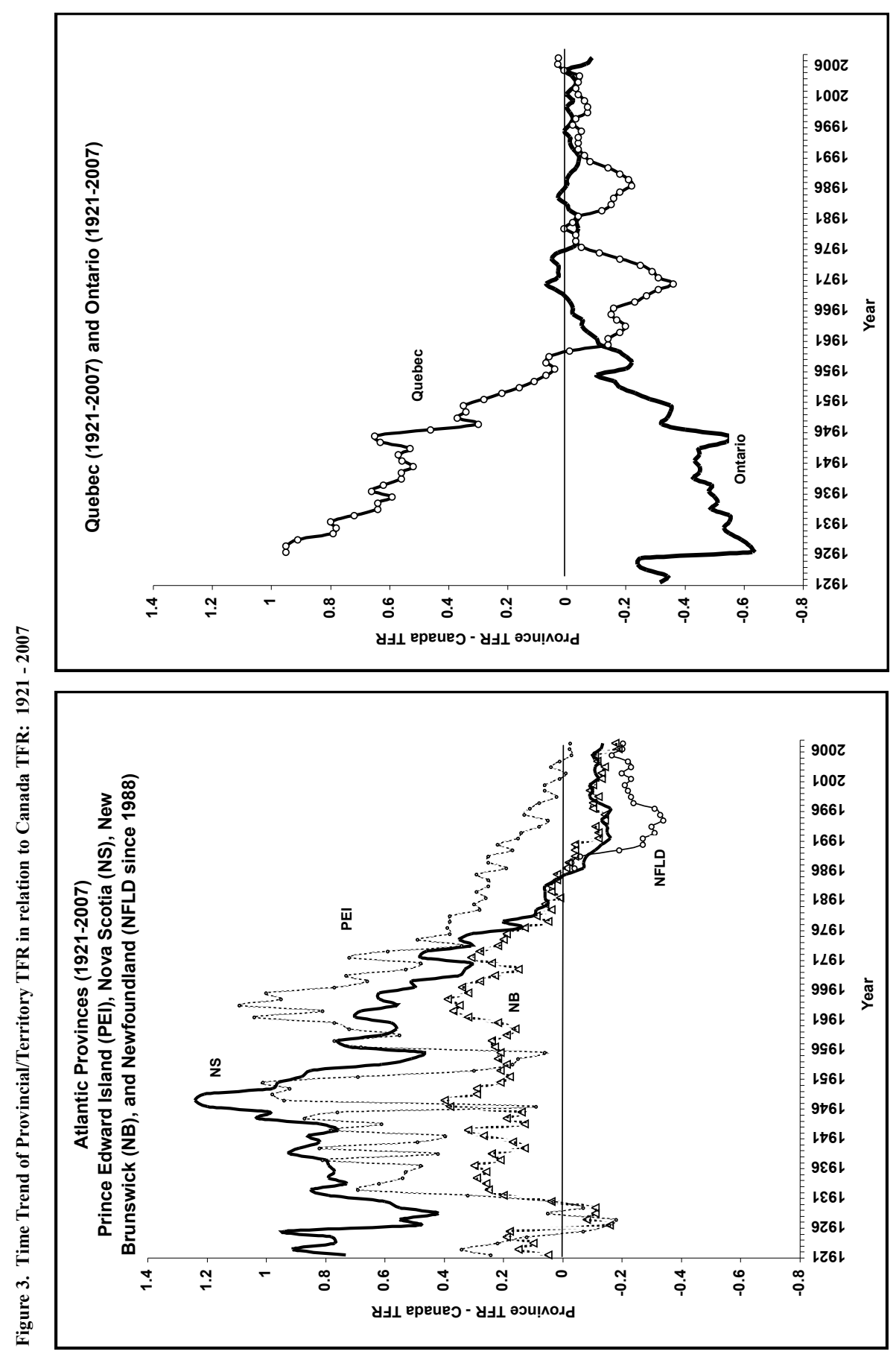

CSP 2010, 37.3-4: 497-524 
Fertility in Alberta in a Context of Economic Growth, 1997-2007

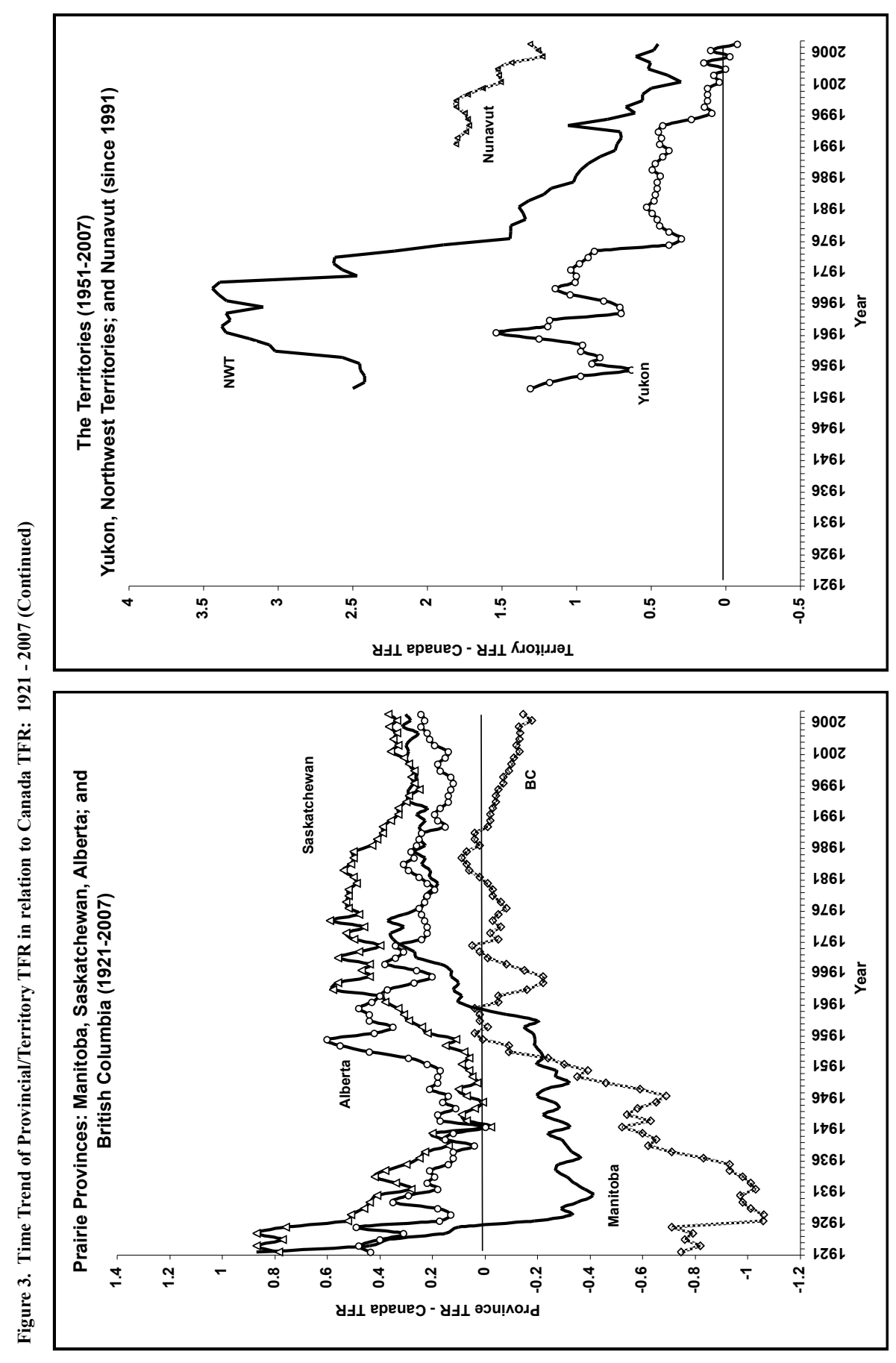

CSP 2010, 37.3-4: 497-524 
have been almost indistinguishable from one another, both being very near to the national average.

In western Canada, the three provinces in the prairies, Saskatchewan, Alberta and Manitoba, have also shown noticeable periods of increase and decline throughout the $20^{\text {th }}$ century, while also maintaining birth rates above those of Canada. By 1926, Manitoba's rate had fallen below the national level but gradually regained above average status by 1961. Fertility in Alberta and Saskatchewan has consistently exceeded the Canadian rate and in recent years, most notably since the early 2000s. Both of these provinces exhibit an upward movement, something that is not noticeable for any of the other provinces. Among the provinces Saskatchewan today maintains the highest total fertility rate, followed closely by Manitoba and Alberta.

On the west coast, British Columbia (BC) presents a very different picture to that of these provinces in the Prairies. From 1921 to about the middle of the 1950s birth rates in $\mathrm{BC}$ have been well below the national average. Convergence with Canada occurred as early as 1956. From the early 1990s, British Columbia, along with Nova Scotia, New Brunswick and Newfoundland, shares the status of having the lowest fertility in Canada.

As to the underlying structural causes of these provincial fertility patterns, undoubtedly variations in demographic composition must account for some of the discrepancies. In the cases of Alberta and Saskatchewan, delayed onset of urbanization and industrialization may help explain their persistent pattern of above average fertility up to the first half of the $20^{\text {th }}$ century (Breen 2006; Hiller 2009, 2000; Stone 1967; McInnis 2000a, 2000b; Ward 1983). However, with specific reference to Alberta's recent fertility upturn, such historical factors would seem to be inconsequential; hence, explanations for this recent phenomenon must be sought in more proximate conditions. The Territories have had above average fertility, though in recent years Yukon has virtually converged with the Canadian average. The much higher birth rates of Northwest Territories and Nunavut reflect the combined influences of geographic isolation and predominantly Aboriginal population in these regions (Romaniuk 1984). Notwithstanding these characteristics, the long-term trend is toward eventual convergence.

\section{Economy and Fertility}

The association of economy with fertility occupies a central concern in social demographic theory. One of the earliest statements on the subject is by Malthus, who postulated an increase in wages would lead to 
increased fertility since higher wages would have the effect of encouraging people to marry early. This relationship, Malthus postulated, would result in excessive population growth unless checked by moral restraint - the abdication of marriage or its postponement to older ages (Malthus 1798). ${ }^{6}$ Malthus's thinking has motivated subsequent macroeconomic theorizing on the role of income and economic opportunities as factors in fertility change (e.g., Leibenstein 1957; Becker 1960, 1992; Davis 1963; Easterlin 1961, 1969, 1983, 1987; Eversley 1965; Kuznets 1969). Two economic perspectives grounded in the experience of advanced societies are the procyclical and the countercyclical explanations; they lead to different predictions concerning economic conditions and fertility (Macunovich 1995). ${ }^{7}$

Procyclical theory posits a positive association between economic conditions and fertility: Periods of sustained economic growth are assumed to translate into increased fertility, whereas periods of economic downturn are expected to produce reduced fertility. Economic recessions usually mean increased levels of socioeconomic uncertainty for households. Under such conditions couples would find it difficult to satisfy their socioeconomic aspirations and would therefore find it prudent to postpone childbearing to the future when conditions improve. Good economic times are thought to have the opposite effects on households' decisions about childbearing. During good times couples can more readily actualize material goals and feel more confident about the future. Consequently they would be more inclined to decide to have children.

Countercyclical theory predicts that fertility rates should increase during economic downturns and decline during good times. This prediction attributes a central role to women's economic opportunities. It assumes households' socioeconomic wellbeing is not solely determined by men's income but also by women's earnings. This means that couples' fertility decisions are conditioned strongly by women's opportunity costs. During good times, period fertility rates would be predicted to stay low or possibly drop because in this type of economic context the value of time for women increases and taking time off work to have children would incur for them significant opportunity costs. Childbearing would mean having to forego earnings and possibly also miss opportunities for advancement in the workplace. During economic recessions the labour force prospects for women usually diminish; consequently their opportunity costs for childbearing would be expected to decline. Under the postulates of the countercyclical theory, this type of situation should translate into increased period fertility rates. 


\section{Fertility in Alberta during 1997-2007: Empirical Analysis}

Table 2 displays various fertility measures for Alberta over the period 1997 to 2007: the number of births, crude birth rates (CBRs), parity specific birth rates, average age at childbearing, and period TFRs. The overall picture in this table is consistent with an overall pattern of fertility increase, though most notably since the early 2000s. Over this period, the number of births amounted to nearly half a million, accounting for CBR increases from 12.9 in 1997 to 14.2 in 2007 . First order TFR rose from 0.697 at the beginning of the period to 0.837 in 2007 (a 20\% increase). The change for higher order TRFs have been relatively small. Overall, average age at maternity (MAC) has been increasing. However, the largest change is associated with first order births. For first births, MAC grew from 26.77 in 1997 to 27.45 in 2007 (an increase of 0.68 of a year); for second births, the change was 29.15 to 29.51 (a difference of 0.36 of a year). Across all birth orders, MAC increased by 0.55 of year, from 28.61 in 1997 to 29.16 in 2007 . These trends in average age at maternity suggest there is some degree of fertility postponement among women in Alberta, notwithstanding the recent fertility increases.

Table 3 looks at the relationship between selected macro level variables and fertility in Alberta during 1997-2007. Due to the small number of data points (11 years) the analysis is confined to zero-order correlations involving a number of economic predictors (unemployment rates of men and women, male and female weekly wages, and female labour force participation), and three social demographic variables (marriage rate, abortion rate and ratio of out of wedlock births to births in wedlock) in relation to overall, first, second, and third order TFRs, respectively. As expected, year is positively correlated with each of the fertility measures; however, the association is significant only for overall TFR and the first-order TFR. This is not surprising since in Alberta, as in other highly developed societies, change in period fertility is most closely affected by change in the incidence of first births and to a lesser extent the timing of higher birth orders (Frejka and Sardon 2004; Delgado et al. 2009).

Change in marriage rates would be expected to correlate closely with change in fertility rates on a lagged basis by two or three years, as most often couples do not have a child in the same year they marry. As seen in Table 2, lagged marriage rates do correlate strongly with overall and first-order TFR, but the direction of association in both instances is counter to expectation. Although a positive relationship was expected, the correlations are negative. This suggests that the fertility increase in Alberta cannot be the result of increased marriage rates. Declines in the incidence of abortion might be expected to perhaps explain increase in 


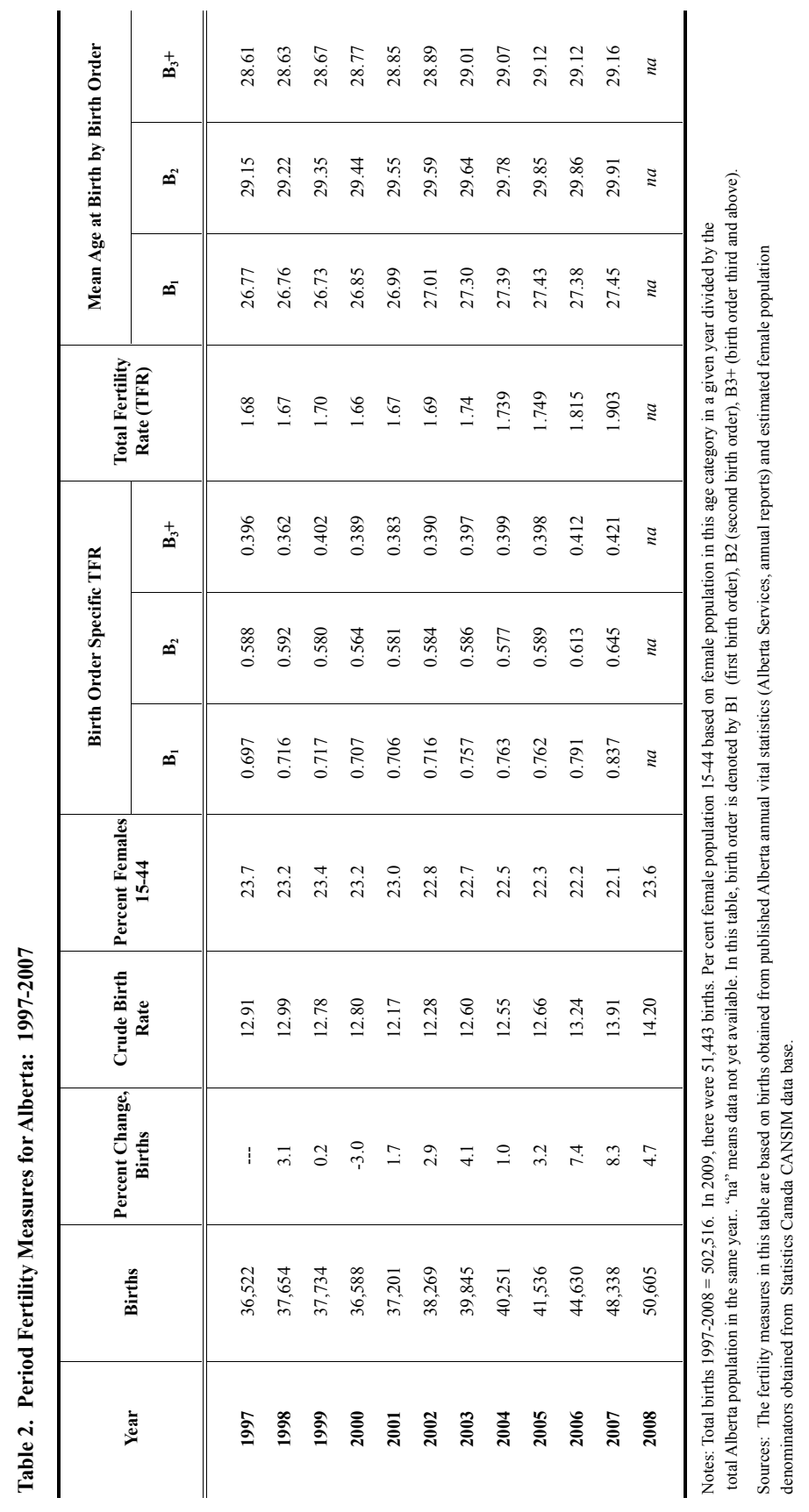

CSP 2010, 37.3-4: 497-524 509 
Table 3

Zero-order Correlations between Selected Structural Variables and TFR Overall and Birth Order Specific TFRs for Alberta: 1997 - 2007

\begin{tabular}{l|c|c|c|c}
\hline \multicolumn{1}{c|}{ Independent Variable } & TFR & TFR(1) & TFR(2) & TFR(3) \\
\hline \hline (1) Year (1997-2007) & $.757^{*}$ & $.866^{*}$ & 0.475 & 0.336 \\
(2) Marriage rate (t-2) & $-.810^{*}$ & $-.911^{*}$ & -0.531 & -0.468 \\
(3) Marriage rate (t-3) & -0.458 & $-.639^{*}$ & -0.164 & -0.381 \\
(4) Log abortion rate (t) & 0.071 & -0.144 & 0.328 & 0.332 \\
(5) No. births out of wedlock & & & \\
$\quad$ No. births in wedlock (t) & $.923^{*}$ & $.926^{*}$ & $.720^{*}$ & $.653^{*}$ \\
(6) Unemployment rate (t) & $-.766^{*}$ & $-.798^{*}$ & -0.512 & -0.358 \\
(7) Unemployment rate (male) (t) & $-.788^{*}$ & $-.811^{*}$ & -0.527 & -0.399 \\
(8) Unemployment rate (female) (t) & $-.707^{*}$ & $-.765^{*}$ & -0.468 & -0.288 \\
(9) Male weekly average wage (t) & $.836^{*}$ & $.885^{*}$ & $.628^{*}$ & 0.445 \\
(10) Female weekly average wage (t) & $.817^{*}$ & $.875^{*}$ & $.614^{*}$ & 0.405 \\
(11) Unemployment rate (male) (t-1) & $-.641^{*}$ & $-.758^{*}$ & -0.450 & -0.270 \\
(12) Unemployment rate (female) (t-1) & $-.659^{*}$ & $-.770^{*}$ & -0.472 & -0.287 \\
(13) Male weekly average wage (t-1) & $.837^{*}$ & $.934^{*}$ & $.628^{*}$ & 0.462 \\
(14) Female weekly average wage (t-1) & $.827^{*}$ & $.898^{*}$ & 0.601 & 0.441 \\
(15) Female labour force & 0.444 & $.600^{*}$ & 0.381 & 0.101 \\
$\quad$ participation rate (t) & & & & \\
\hline
\end{tabular}

Note: $\operatorname{TFR}\left({ }_{1}\right), \operatorname{TFR}(2)$ and $\operatorname{TFR}\left({ }_{3}\right)$ are TFRs for birth orders 1,2 and 3 , respectively. * means statistically significant correlations ( $p \leq .05$, two-tailed test), ( $\mathrm{t}$ ) means variable is for current year; (t-1) means variable lagged by one year.

Sources: for variables (2) to (5): Alberta Services (1997-2007) Alberta Vital Statistics Annual Review, and Statistics Canada CANSIM data base (for female population, Table 051-0010 Estimates of Population by Marital Status, Age Group and Sex); Alberta Reproductive Health Report Working Group (2008); Alberta Reproductive Health:

Pregnancies \& Births Table Update 2007 (Alberta Health and Wellness). Sources for variables (6) to (15):

Statistics Canada CANSIM data base, labour force tables 282-0069 and 282-0001. 
total fertility. However, the abortion rate shows no significant correlation with fertility in this case. The ratio of the number of births out-ofwedlock has in many industrialized societies been on the rise in recent years. The same might be expected for Alberta. From the results in Table 3 , the ratio of births out-of-wedlock to the number in wedlock is indeed positively correlated with total fertility rate and with TFR for first order births, though only moderately with second and third order TFRs.

Concerning the economic variables, unemployment shows a robust inverse relationship with total fertility and first order TFR, suggesting that periods of economic growth are conducive to increased fertility while economic downturn with lower fertility, especially with respect to first births. Male and female unemployment rates (current and lagged by one year) correlate significantly with overall TFR and the first order TFR in inverse direction: the higher the unemployment, the lower the fertility. Similarly, male and female average weekly wages (current and lagged) are both positively correlated with these two fertility measures, indicating that economic wellbeing is an important stimulus for childbearing. The lagged male wage variable is also correlates significantly with the second order TFR. Female labour force participation is moderately associated with first order TFR though unrelated to the other fertility measures.

\section{Discussion and Conclusion}

Alberta represents an interesting case of a population that, after many years of sub-replacement fertility stretching back to the mid 1970s, has witnessed a recent unexpected and sustained fertility increase, such that by 2007 , its TFR had grown close to the replacement level. ${ }^{8}$ These fertility gains took place during a period of unprecedented economic growth in this province. The argument posed in this investigation was that this sustained period of economic growth may have created a socioeconomic context favorable to childbearing. Though not conclusive, the empirical evidence examined suggests that the fertility upswing in Alberta during 1997-2007 has been driven primarily by an ostensible increase in first-order births, and to a lesser extent second-order births. The empirical results based on correlations of birth order specific fertility rates with a series of macro level variables, seem more consistent with the procyclical explanation of fertility change. Fertility has increased in Alberta when socioeconomic conditions for households have been improving and incomes rising. Buoyant economic times have presented couples with a greater sense of confidence in their perceived ability to satisfy long term child quality aspirations (i.e., invest more resources on 
their progeny) as well in their ability to satisfy household material goals (e.g., buying a new house). The positive economic outlook may have allowed couples to better absorb opportunity costs associated with women taking time off work to have children. Recent cross-national evidence based on the experience of highly developed countries lends credence to this procyclical interpretation.

Until recently, in many of the most advanced societies variables such as female labour force participation and education correlated inversely with fertility rates. However, since about 1980, these relationships, particularly that between female labour force participation and fertility, have turned positive (Rindfuss et al. 2003; Billari and Kohler 2004; Engelhardt, Kogel and Prskawetz 2004; Adserá 2004, 2005). This suggests that in the context of advanced societies, socioeconomic gains, particularly with regard to women's economic opportunities, can translate into fertility increases.

Myrskyla, Kohler and Billari (2009) have presented further evidence of a positive association between socioeconomic improvements at the societal level and fertility increases. As would be expected, these researchers found a strong inverse association between a country's level of socioeconomic well-being (as measured by the UN's Human Development Index (HDI)) and total fertility. However, they also noted that at higher levels of HDI further advancements on this measure are associated with an upward shift in period fertility rates (see also Tuljapurkar 2009). ${ }^{9}$

Similarly, Goldstein, Sobotka and Jasilioniene (2009) have documented fertility increases in a large number of lowest-low fertility countries. According to these authors, the fertility increases are partly attributable to "improving economic conditions" in these countries (p. $683)^{10}$

Finally, a recent cross-national analysis by Orsal and Goldstein (2010: 11) based on 22 OECD countries between 1976 to 2008, shows that both male and female unemployment rates have procyclical relationship with total fertility. In other words, "in good economic conditions fertility increases, whereas bad economic conditions lead to a decline in fertility."

In the case of Alberta, a number of questions remain for future research. First, it would be important to assess the extent to which institutional policies may have stimulated fertility increases in this province. Family-friendly policies (i.e., more generous maternity benefits for women, easier access to childcare, etc.) may have played a role in the note fertility increase. Second, given its strong economic performance in recent years Alberta has attracted many migrants from other parts of Canada and abroad. The possible contribution of migrant fertility should 
be examined. Third, the analysis executed in this study should be extended to the other Canadian provinces in order to provide a broader perspective on provincial and regional variations in fertility in Canada. As was noted earlier, there is indication that the Prairie Provinces in particular represent a region of relatively high fertility. This warrants further systematic investigation. Fourth, additional insight into the role of macroeconomic conditions on fertility change could be gained through a more extensive analysis based on longer time series stretching back to the early 1970s, just prior to the onset of Alberta's first economic boom. This type of analysis should be conducted separately for different birth orders. Finally, based on the data examined earlier (Table 2) regarding change in average age at maternity, it appears that Alberta may have entered the final stage of the postponement transition (Goldstein, Sobotka and Jasilioniene 2009). This question deserves further attention.

\section{Acknowledgements}

The author is grateful to the anonymous reviewers for their helpful comments and suggestions for revision. It goes without saying that any errors are the sole responsibility of the author. Thanks also to Abu SadaW Nurullah and Kamrul Islam for their helpful research assistance in the preparation of this paper. This research was funded by a Grant from the Social Sciences Research Council of Canada (Grant No. 410-2009-0160). Additional funding was received from the Killam Research Fund, University of Alberta, and We Society of Edmonton Demographers. $\mathrm{QThe}$ support of these funding sources is gratefully acknowledged.

\section{End Notes}

1. Beside its sociological significance, increases in total fertility following a long period of low reproductive levels implies important long term demographic benefits for a population, including a slower pace of demographic aging, and less reliance on immigration as a source of future labor supply.

2. The actual number of births in 2008 was 50,604 . For 2009 , Alberta Services has reported a record-breaking 51,443 births (Hall 2010). With a population of just over 3.5 million, this figure in 2009 accounts for a crude birth rate of slightly over 14 per 1000 population. 
3. The birth surge in Alberta has caught the attention of the news media, and various stories have appeared linking this phenomenon to buoyant economic times (see for example: Libin 2007; Walton 2006; Sadava 2008; Priest 2008; Audette 2007; Derworiz 2009; Hall 2010).

4. According to some experts, the Alberta economy is expected to recover once energy prices rise, namely increases in the price of natural gas and oil (The Globe and Mail, Wednesday July 15, 2009, Thursday April 9, 2009; January 22, 2010).

5. 1921 is the year when the Canadian vital registration system was instituted. The data for the historical overview of fertility are from Statistics Canada publications. Data for 1921-1990: Table 10, Selected Birth and Fertility Statistics, Canada, 1921-1990, Cat. No. 82553; for subsequent years, annual Vital Statistics, Births, and CANSIM data base.

6. Malthus also postulated that the less preferable alternative to moral restraint is "vice and misery" (i.e., allowing nature's "positive checks" to stabilize population).

7. Although first developed by Dorothy Thomas (1927) the procyclical thesis of economy and fertility is closely connected to the work of Easterlin $(1969,1978,1987)$; the countercyclical thesis is connected to the work of Butz and Ward (1979).

8. In many low fertility populations, where birth rates have fluctuated around an average of 1.3 children per woman, and in some cases even lower (Billari and Kohler 2004; Kohler, Billari and Ortega 2002; Sobotka 2004; Goldstein, Sobotka and Jasilioniene 2009), widespread fertility postponement among cohorts of women born after World War II has contributed to this. Reflecting on this phenomenon, some scholars have asserted that recent cohorts of women are unlikely to achieve replacement fertility in the future when they reach the end of their childbearing years (Frejka and Sardon 2004). Others have speculated that low fertility societies have seen the emergence of a new mindset among young adults whereby childlessness has become a desirable and socially acceptable alternative to parenthood, and it is therefore entirely possible that completed fertility for these generations will well below the 2.1 replacement level (Lutz, Skirbekk and Testa 2006; Caldwell and Shindlemayr 2003; Lesthaeghe 1995). 
9. Specifically, further increases in Human Development above a value of 0.86 ( 1.0 being the maximum possible value) is associated with increased fertility (Myrskyla, Kohler and Billari 2009).

10. Another important finding by these authors was that immigrant fertility has helped, in varying degrees, to raise birth rates in such societies, even though total fertility remains considerably removed from the 2.1 replacement level.

\section{References}

Adserá, A. 2005. Vanishing children: from high unemployment to low fertility in developed countries. American Economic Review 95 (2): 189-193.

Adserá, A. 2004. Changing fertility rates in developed countries. The impact of labor market institutions. Journal of Population Economics 17: 17-43.

Alberta Employment, Immigration and Industry. 2007. Annual Alberta Regional Labour Market Review. Edmonton, Alberta.

Alberta Health and Wellness. 2009. Births Data Base. www.health.ahinform@gov.ab.ca (accessed July 29, 2009).

Alberta Reproductive Health Working Group. 2009. Alberta Reproductive Health: Pregnancies and Births 2009. Edmonton, Alberta: Alberta Health and Wellness.

Alberta Reproductive Health Report Working Group. 2008. Alberta Reproductive Health: Pregnancies \& Births Table Update 2007. Edmonton, Alberta: Alberta Health and Wellness.

Audette, T. 2007. Mini baby boon on base mirrors rest of Alberta: Province retains title as country's top baby producer. Edmonton Journal (Monday, September 13).

Balakrishnan, T. R., E. Lapierre-Adamcyk and K. J. Krotki. 1993. Family and Childbearing in Canada. Toronto: University of Toronto Press. 
Becker, G. S. 1992. Fertility and the economy. Journal of Population and Economics 5: 185-201.

Becker, G. S. and R. J. Barro. 1988. A reformulation of the economic theory of fertility. Quarterly Journal of Economics 103: 1-25.

Becker, G. S. 1960. An economic analysis of fertility, in Demographic and Economic Change in Developed Countries. A Conference of the Universities, National Bureau Committee for Economic Research, Special Conference Series 11. Princeton: Princeton University Press.

Billari, F. and H.-P. Kohler. 2004. Patterns of low and lowest-low fertility in Europe. Population Studies 58(2): 161-176.

Bongaarts, J. 1978. A framework for analyzing the proximate determinants of fertility. Population and Development Review 4: $105-132$.

Bongaarts, J. and G. Feeney. 2000. On the quantum and tempo of fertility: A reply. Population and Development Review 26(3): 560-564.

Bongaarts, J. and G. Feeney. 1998. On the quantum and tempo of fertility. Population and Development Review 24(2): 271292.

Butz, W. and M. Ward. 1979. Will US fertility remain low? A new economic interpretation. Population and Development Review 5(4): 663-688.

Breen, D. 2006. The making of modern Alberta, in Alberta Formed Alberta Transformed, edited by Michael Payne, Donald Wetherell and C. Cavanaugh, Edmonton: University of Alberta Press and University of Calgary Press, pp. 539-566.

Caldwell, J. C. 1981. Theory of Fertility Decline. New York: Academic Press.

Caldwell, J. C. and T. Schindlmayr, 2003. Explanations of the fertility crisis in modern societies: A search for commonalities. Population Studies 57(3): 241-263. 
Cross, P. and G. Bowlby. 2006. The Alberta economic juggernaut: The boom on the rose. Canadian Economic Observer (December 2006): 3.1-3.12.

Davis, K. 1963. The theory of change and response in modern demographic history. Population Index 29(4): 345-366.

Davis, K. and J. Blake. 1954. Social structure and fertility: an analytical framework. Economic Development and Cultural Change 4(3): 211-235.

Delgado, M., A. De Rose, L. Barrios and F. Z. Lopez. 2009. The delay of maternity and its causes: An analysis of the timing of the first child in Spain. Genus 65(2): 79-111.

Derworiz, C. 2009. Keeping track of hatches, matches and dispatches: Alberta's vital statics mirrored the boom in 2007. Calgary Herald (Tuesday, April 19).

Easterlin, R. E. 1987. Birth and Fortune (2nd edition). Chicago: University of Chicago Press.

Easterlin, R. E. 1983. Modernization and fertility: a critical essay, in Determinants of Fertility in Developing Countries. Volume 2, edited by Rodolfo A. Bulatao and Ronald D. Lee. New York: Academic Press, pp. 562-586.

Easterlin, R. A. 1969. Toward an economic theory of fertility: survey of recent research on economic factors in American fertility, in Fertility and Family Planning: A World View, edited by S.J. Behrman, Leslie Corsa Jr. and Ronald Freedman. Ann Arbor: The University of Michigan Press, pp. 127-156.

Easterlin, R. A. 1961. The American baby boom in historical perspective. American Economic Review 51: 869-911.

Edmonton Journal. 2009. Alberta influx cools with economy. (Thursday, December 24): D1. 
Engelhardt, H., T. Kogel and A. Prskawetz. 2004. Fertility and women's employment reconsidered: A macro-level time-series analysis for developed countries, 1960-2000. Population Studies 58(1): 109-120.

Eversley, D. E. C. 1965. Population, economy and society, in Population in History: Essays in Historical Demography, edited by D. V. Glass and D. E. C. Eversley. Chicago: Aldine, pp. 23-69.

Ermisch, J. F. 2003. An Economic Analysis of the Family. Princeton: Princeton University Press.

Ermisch, J. F. 1988. Econometric analysis of birth rate dynamics in Britain. Journal of Human Resources 23(4): 563-576.

Frejka, T. and J.-P. Sardon. 2004. Childbearing Trends and Prospects in Low-Fertility Countries. Dordrecht: Klewer Academic Publishers.

Goldstein, J. R. and T. Cassidy. 2010. Cohort postponement and period measures. Paper presented at the annual meetings of the Population Association of America. Dallas, Texas. April 15-17.

Goldstein, J. R., T. Sobotka and A. Jasilioniene. 2009. The end of lowest-low fertility? Population and Development Review 35(4): 663-699.

Grindstaff, C. F. 1995. Canada's continued trend of low fertility. Canadian Social Trends (Winter): 12-16.

Grindstaff, C. F. 1985. The baby bust revisited: Canada's continuing pattern of fertility. Canadian Studies in Population 12(1): 103110 .

Grindstaff, C. F. 1975. The baby bust: Changes in fertility patterns in Canada. Canadian Studies in Population 2: 15-22.

Hall, J. 2010. Ethan and Olivia Alberta's top baby names for 2009. Edmonton Journal. February 18: www.edmontonjournal.com (accessed February 19, 2010). 
Fertility in Alberta in a Context of Rapid Economic Growth, 1997-2007

Haub, C. 2009. The U.S. Recession and the birth rate. Population Reference Bureau website: www.prb.org/Articles/2009/usrecessionandbirthrate.aspx (accessed July 29, 2010).

Hiller, H. H. 2009. Second Promised Land: Migration to Alberta and the Transformation of Canadian Society. Kingston and Montreal: McGill-Queen's Press.

Hiller, H. H. 2000. Canadian Society: A Macro Analysis. Toronto: Prentice Hall Canada.

Hirschman, C. 1994. Why fertility changes. Annual Review of Sociology 20: 203-233.

Hyatt, D. E. and W. J. Milne. 1991. Countercyclical fertility in Canada: some empirical results. Canadian Studies in Population 18(1): 1-16.

Kim, Y. J. and R. Schoen. 2000. On the quantum and tempo of fertility: Limits to the Bongaarts-Feeney Adjustment. Population and Development Review 26(3): 554-559.

Kohler, H.-P., F. Billari and A. Ortega. 2002. The emergence of lowest-low fertility in Europe during the 1990s. Population and Development Review 28(4): 641-680.

Kuznets, S. 1969. Economic Aspects of Fertility Trends in the Less Developed Countries, in Fertility and Family Planning: A World View, edited by S.J. Behrman, Leslie Corsa Jr. and Ronald Freedman. Ann Arbor: The University of Michigan Press, pp. 157-179.

Lapierre-Adamcyk, E. and C. Charvet. 2000. Cohabitation and marriage: An assessment of research in demography. Canadian Studies in Population 27(1): 239-254.

Le Bourdais, C. and ( . Lapierre-Adamcyk. 2004. Changes in conjugal life in Canada: Is cohabitation progressively replacing marriage? Journal of Marriage and Family 66: 929-942. 
Leibenstein, H. 1957. Economic Backwardness and Economic Growth: Studies in the Theory of Economic Development. New York: John Wiley.

Lesthaeghe, R. 1995. The second demographic transition in western countries: An interpretation, in Gender and Family Change in Industrialized Countries, edited by Karen Oppenheimer Mason and A.-M. Jensen. Oxford: Clarendon Press, pp. 17-62.

Lesthaeghe, R. and J. Surkyn. 1988. Cultural dynamics and economic theories of fertility change. Population and Development Review 14(1):1-45.

Libin, K. 2007. Labour pains grip Alberta: baby hospital proposed. Good times result in biggest baby boom since '80s. National Post (Friday, January 12).

Lutz, W., V. Shirbekk and M. T. Testa. 2006. The lowfertility trap hypothesis: forces that may lead to further postponement and fewer births in Europe. Vienna Yearbook of Demographic Research 2006: 167-192.

Macunovich, D. J. 1995. The Butz-Ward fertility model in the light of more recent data. The Journal of Human Resources 30(2): 229255.

Malthus, T. R. 1798. An Essay on the Principle of Population as it Affects the Future Improvement of Society. London: J. Johnson Publisher.

Marsh, J. H. 2006. Alberta's quiet revolution: 1973 and the early Lougheed years, in Alberta Formed Alberta Transformed, edited by Payne, Michael, Donald Wetherell and C. Cavanaugh. Edmonton: University of Alberta Press and University of Calgary Press, pp. 643-676.

McInnis, M. 2000a. The population of Canada in the Nineteenth Century, in A Population History of North America, edited by Michael R. Haines and Richard H. Steckel. Cambridge: Cambridge University Press, pp. 371-432. 
Fertility in Alberta in a Context of Rapid Economic Growth, 1997-2007

McInnis, M. 2000b. Canada's Population in the Twentieth Century, in A Population History of North America, edited by

Michael R. Haines and Richard H. Steckel. Cambridge: Cambridge University Press, pp. 529-600.

Myrskyla, M., H.-P. Kohler and Francesco C. Billari. 2009.

Advances in development reverse fertility declines. Nature 460 (August 6): 741-743.

Ni Bhrolcháin, M. and L. Toulemon. 2005. Does postponement explain the trend to later childbearing in France? Vienna Yearbook of Population Research 2005: 83-108.

Orsal, D., D. Karaman and J. Goldstein. 2010. The increasing importance of economic conditions on fertility. Paper presented at the annual meetings of the Population Association of America. Dallas, Texas, April 15-17.

Owram, D. 2006. Oil's magic wand, in Alberta Formed Alberta Transformed, edited by Payne, Michael, Donald Wetherell and C. Cavanaugh. Edmonton: University of Alberta Press and University of Calgary Press, pp. 567-588.

Parkland Institute. 2007. The Spoils of the Boom: Income, Profits and Poverty in Alberta. Edmonton: University of Alberta.

Priest, L. 2008. Canada's U.S. baby boom: With neonatal resources stretched thin, more and more high-risk infants are sent south to find a bed. The Globe and Mail (Monday, May 5): A1 and A7.

Rindfuss, R., K. Benjamin Guzzo and P. S. Morgan. 2003.

The changing institutional context of low fertility. Population Research and Policy Review 22(5-6): 411-438.

Romaniuc, A. 1984. From Baby-boom to Baby-bust. Ottawa: Minister of Supply and Services Canada and Statistics Canada. Catalogue no. 91-524E.

Sadava, M. 2008. Child-care crunch put parents in bind. Edmonton Journal (Saturday, April 26): A1 and A2.

Schoen, R. 2006. Dynamic Population Models. Dordrecht, Netherlands: Springer. 
Schoen, R. 2004. Timing effects and the interpretation of period fertility. Demography 41(4): 801-819.

Service Alberta (1997-2007). Alberta Vital Statistics Annual Review. Edmonton, Alberta.

Sobotka, T. 2009. The likely increase of fertility in Europe. Paper presented at the XXVI International Union for the Scientific Study of Population (IUSSP) conference (Session 82). Marrakech, Morocco. September 29, 2009.

Sobotka, T. 2004. Is lowest-low fertility in Europe explained by the postponement of childbearing? Population and Development Review 30 (2): 195-220.

Spengler, J. J. 1972. Demographic Factors and Early Modern Economic Development, in Population and Social Change, edited by D.V. Glass and Roger Revelle. London: Edward Arnold, pp. 87-98.

Statistics Canada. 2008. Earnings and Incomes of Canadians over the past Quarter Century. 2006 Census (Cat. No. 97-563-X).

Statistics Canada. 2009a. Table 282-0069 - Labour force survey estimates (LFS), wages of employees by type of work, National Occupational Classification for Statistics (NOC-S), sex and age group, unadjusted for seasonality, monthly dollars. CANSIM database: $\underline{\text { http://estat.statcan.gc.ca/cgi- }}$ win/cnsmcgi.exe?Lang=E\&amp;EST-Fi=EStat/English/CII_1eng.htm (accessed July 29, 2009).

Statistics Canada. 2009b. Table 282-0001 - Labour force survey estimates (LFS), by National Occupational Classification for Statistics (NOC-S) and sex, annual. CANSIM database: http://estat.statcan.gc.ca/cgiwin/cnsmcgi.exe?Lang=E\&amp;EST-Fi=EStat/English/CII_1eng.htm (accessed July 29, 2009).

Stone, L. O. 1967. Urban Development in Canada. Ottawa: Dominion Bureau of Statistics: Minister of Industry, Science and Technology. 
Fertility in Alberta in a Context of Rapid Economic Growth, 1997-2007

The Globe and Mail. 2009. Why economists are watching paint dry:

The buyers are back, home sales are surging, and white paint is part of the picture. It's used on everything from houses to skyscrapers, and sales are picking up. (Wednesday, July 15): A1 and A5.

The Globe and Mail. 2010. 'The West is on fire': Energy deals fuels revival. (Friday, January 22): B1 and B2.

The Globe and Mail. 2009. Alberta buoyed as oil sands show signs of life. (Monday, June 22): A7.

The Globe and Mail. 2009. Healthy savings and no debt will save Alberta: its financial flexibility seen as helping it weather a \$4.7-billion deficit, financial experts say. (Thursday, April 9): A6.

Thomas, D. S. 1927. Social Aspects of the Business Cycle. New York: Alfred A. Knopf.

Tuljapurkar, S. 2009. Demography: Babies make a comeback. Nature 460 (August 6): 693-694.

van Imhoff, E. and N. Keilman. 2000. On the quantum and tempo of fertility: Comment. Population and Development Review 26(3): 549-553.

Walton, C. D. 2006. Calgary baby boom has hospitals scrambling. The Globe and Mail (Thursday, March 2): A3.

Ward, P. W. 1983. Population growth in the Western Canada, 18911912, in The Developing West, edited by John E. Foster. Edmonton: University of Alberta Press, pp. 179-200.

Wu, Z. 2000. Cohabitation: An Alternative Form of Family Living. Toronto: Oxford University Press. 
Appendix A

Data Series for the Independent Variables in Table 3

\begin{tabular}{|c|c|c|c|c|c|}
\hline Year & $\begin{array}{c}\text { Marriage Rate } \\
\text { (t) }\end{array}$ & $\begin{array}{c}\text { Marriage Rate } \\
\text { (t-2) }\end{array}$ & $\begin{array}{c}\text { Marriage Rate } \\
(t-3)\end{array}$ & $\begin{array}{l}\text { Log Abortion } \\
\text { Rate (t) }\end{array}$ & $\begin{array}{c}\text { Unemploymen } \\
\text { Rate (t) }\end{array}$ \\
\hline 1997 & 6.40 & 6.90 & 6.96 & 2.59 & 5.90 \\
\hline 1998 & 6.50 & 6.56 & 6.90 & 2.54 & 5.60 \\
\hline 1999 & 6.50 & 6.40 & 6.56 & 2.53 & 5.70 \\
\hline 2000 & 6.30 & 6.54 & 6.40 & 2.55 & 5.00 \\
\hline 2001 & 6.00 & 6.46 & 6.54 & 2.52 & 4.60 \\
\hline 2002 & 6.00 & 6.27 & 6.46 & 2.49 & 5.30 \\
\hline 2003 & 5.80 & 5.99 & 6.27 & 2.48 & 5.10 \\
\hline 2004 & 5.70 & 6.00 & 5.99 & 2.48 & 4.60 \\
\hline 2005 & 5.60 & 5.81 & 6.00 & 2.48 & 3.90 \\
\hline 2006 & 5.80 & 5.69 & 5.81 & 2.53 & 3.40 \\
\hline 2007 & 5.70 & 5.58 & 5.69 & 2.55 & 3.50 \\
\hline Year & $\begin{array}{c}\text { Male } \\
\text { Unemployment } \\
\text { Rate (t) }\end{array}$ & $\begin{array}{c}\text { Female } \\
\text { Unemployment } \\
\text { Rate (t) }\end{array}$ & $\begin{array}{c}\text { Male } \\
\text { Unemployment } \\
\text { Rate (t-1) }\end{array}$ & $\begin{array}{c}\text { Female } \\
\text { Unemployment } \\
\text { Rate (t-1) }\end{array}$ & Male Wages (t) \\
\hline 1997 & 5.70 & 6.10 & 7.00 & 6.80 & 678.77 \\
\hline 1998 & 5.80 & 5.40 & 6.10 & 6.10 & 696.06 \\
\hline 1999 & 5.90 & 5.50 & 5.40 & 5.40 & 713.52 \\
\hline 2000 & 4.90 & 5.00 & 5.50 & 5.50 & 736.22 \\
\hline 2001 & 4.80 & 4.50 & 5.00 & 5.00 & 773.90 \\
\hline 2002 & 5.60 & 4.90 & 4.50 & 4.50 & 835.05 \\
\hline 2003 & 5.20 & 4.90 & 4.90 & 4.90 & 818.50 \\
\hline 2004 & 4.50 & 4.70 & 4.90 & 4.90 & 832.95 \\
\hline 2005 & 3.90 & 4.00 & 4.70 & 4.70 & 886.20 \\
\hline 2006 & 3.30 & 3.60 & 4.00 & 4.00 & 980.81 \\
\hline 2007 & 3.30 & 3.70 & 3.60 & 3.60 & 1004.87 \\
\hline Year & $\begin{array}{c}\text { Female Weekly } \\
\text { Wages } \\
\text { \$(t) }\end{array}$ & $\begin{array}{c}\text { Female Weekly } \\
\text { Wages } \\
\text { \$(t-1) }\end{array}$ & FLFPR (t) & $\begin{array}{l}\text { Number of } \\
\text { Births in } \\
\text { Wedlock (t) }\end{array}$ & $\begin{array}{l}\text { Number of } \\
\text { Births out of } \\
\text { Wedlock (t) }\end{array}$ \\
\hline 1997 & 429.91 & 410.29 & 58.67 & 26866 & 10171 \\
\hline 1998 & 436.72 & 429.91 & 60.44 & 27753 & 10364 \\
\hline 1999 & 448.71 & 436.72 & 60.61 & 27659 & 10655 \\
\hline 2000 & 464.88 & 448.71 & 60.83 & 26867 & 10288 \\
\hline 2001 & 519.60 & 464.88 & 64.08 & 27388 & 10364 \\
\hline 2002 & 528.49 & 519.60 & 63.85 & 27941 & 10809 \\
\hline 2003 & 527.89 & 528.49 & 63.80 & 29105 & 11237 \\
\hline 2004 & 544.34 & 527.89 & 63.80 & 29164 & 11578 \\
\hline 2005 & 610.54 & 544.34 & 60.40 & 29910 & 12109 \\
\hline 2006 & 622.63 & 610.54 & 63.70 & 31679 & 13414 \\
\hline 2007 & 683.81 & 622.63 & 65.80 & 34131 & 14710 \\
\hline
\end{tabular}

CSP 2010, 37.3-4: 497-524 